\title{
Use of antivenoms for the treatment of envenomation by Elapidae snakes in Guinea, Sub-Saharan Africa
}

\author{
Mamadou C Baldé ${ }^{1}$, Jean-Philippe Chippaux ${ }^{2,3^{*}}$, Mamadou Y Boiro ${ }^{1}$, Roberto P Stock ${ }^{4}$ and Achille Massougbodji ${ }^{3}$
}

\begin{abstract}
Background: In Guinea Elapids are responsible for $20 \%$ of envenomations. The associated case fatality rate (CFR) ranged $15-27 \%$, irrespective of treatment.

Results: We studied 77 neurotoxic envenomations divided in 3 groups: a set of patients that received only traditional or symptomatic treatments, and two other groups that received either 2 or 4 initial vials of Antivipmyn ${ }^{\circledR}$ Africa renewed as necessary. CFR was 27.3\%, 15.4\% and 17.6\%, respectively. Although antivenom treatment was likely to reduce CFR, it didn't seem to have an obvious clinical benefit for the patients, suggesting a low treatment efficacy. Mean delay to treatment or clinical stages were not significantly different between the patients who recovered and the patients who died, or between groups. Interpretation of these results is complicated by the lack of systematic studies under comparable conditions. Of particular importance is the absence of assisted ventilation, available to patients in all the other clinical studies of neurotoxic envenomation.

Conclusion: The apparent lack of clinical benefit may have several causes. The hypothesis of a limited therapeutic window, i.e. an insufficient formation of antigen-antibody complexes once toxins are bound to their targets and/or distributed beyond the reach of antivenom, should be explored.
\end{abstract}

Keywords: Elapid, Neurotoxins, Treatment, Antivenom, Guinea, Africa

\section{Background}

The efficacy of immunotherapy and its role in the treatment of envenomation are well established and not in question, at least in Africa [1,2]. The limited availability of antivenoms has led several manufacturers from emergent countries to propose their services to alleviate this critical deficit [3-6]. Two clinical studies conducted in northern Cameroon in 1993 and 1996 established the safety of $\mathrm{F}\left(\mathrm{ab}^{\prime}\right)_{2}$-based antivenoms administered by perfusion or direct intravenous injection $[7,8]$. Between 2005 and 2006, a clinical study using Antivipmyn ${ }^{\circledR}$ Africa, with results judged to be very successful, was conducted in Benin [9]. However, these clinical studies were concerned essentially with envenomations caused by Viperidae, particularly Echis ocellatus, a species

\footnotetext{
* Correspondence: jean-philippe.chippaux@ird.fr

${ }^{2}$ Institut de Recherche pour le Développement, Cotonou, Bénin

${ }^{3}$ Centre d'Etude et de Recherche sur le Paludisme Associé à la Grossesse et à

I'Enfance, Cotonou, Bénin

Full list of author information is available at the end of the article
}

largely predominant in the savannas of West Africa. A clinical study in Guinea confirmed the apparent general efficacy and safety of Antivipmyn ${ }^{\circledR}$ Africa [10]. However, it revealed shortcomings regarding the treatment of envenomations by Elapidae.

We have reexamined the available records in Upper and Lower Guinea (Figure 1) to evaluate the efficacy and shortcomings of immunotherapy relative to the absence of specific treatment in patients with overt neurological symptoms due to envenomation by African Elapidae. Patients were divided into three groups according to treatment protocol.

\section{Methods}

An initial group of 33 patients was retrospectively composed after assemblage of clinical information from hospitalization registries of a health center in the region of Kankan (Upper Guinea). None of them had received antivenom as it was unavailable at that time. Two other groups were based on prospective clinical studies at the 


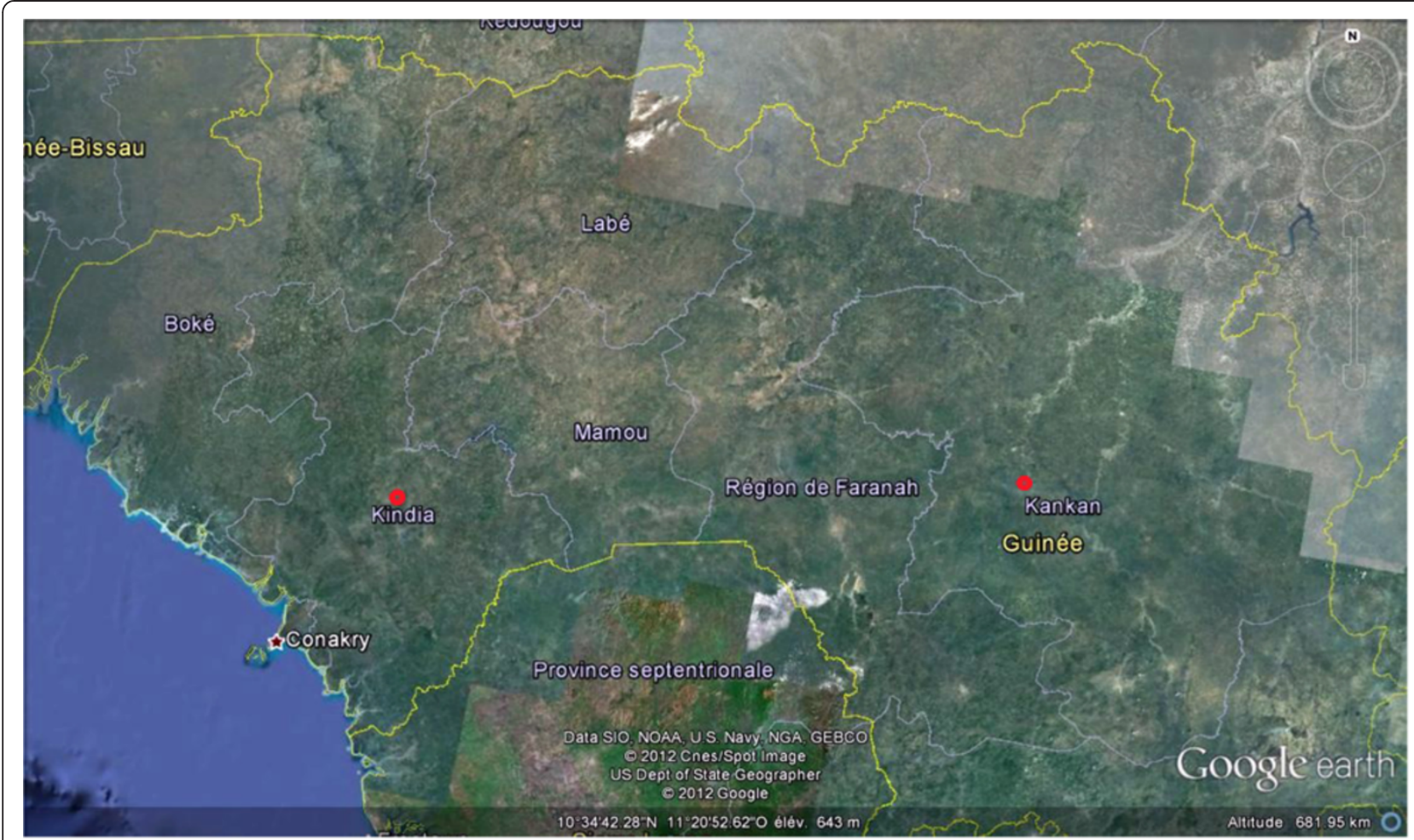

Figure 1 Location of survey sites in Guinea.

Pasteur Institute of Guinea in Kindia (Lower Guinea) in order to ascertain the safety and efficacy of Antivipmyn ${ }^{\circledR}$ Africa under real field conditions, the results of which have been published elsewhere [10]. The second group included 26 patients who were treated during the years 2009 and 2010. Patients received an initial dose of 2 vials of antivenom renewed as a function of clinical evolution 3, 6, 12 and 24 hours after the first dose (low-dose group). Since the results appeared unsatisfactory, the design of the study was amended in 2011 to increase the dose of antivenom accordingly. The third group included 18 patients (but only 17 treated because one died on arrival before treatment). They received twice the initial dose (4 vials), renewed as a function of evolution 3, 6, 12 and 24 hours after the initial dose (high-dose group).

\section{Table 1 Gradation of neurological symptoms}

\begin{tabular}{ll}
\hline Score & Symptoms \\
\hline Grade 1 & Local paraesthesia (anesthesia, tingling, stinging) \\
Grade 2 & Hypersecretion (sweat, saliva) \\
Grade 3 & Impaired vision, hearing, speech, dysphagia \\
Grade 4 & Bilateral ptosis \\
Grade 5 & Severe dyspnea \\
Grade 6 & $\begin{array}{l}\text { Severe consciousness disorders, motor and } \\
\text { respiratory paralysis }\end{array}$ \\
\hline
\end{tabular}

We included all bitten patients who had presented neurological disorders: local paresthesia, tremors and muscular contractions, palpebral ptosis, vision impairment, tinnitus, dysarthria, consciousness disorders, dyspnea, hypersecretion. The severity and surveillance

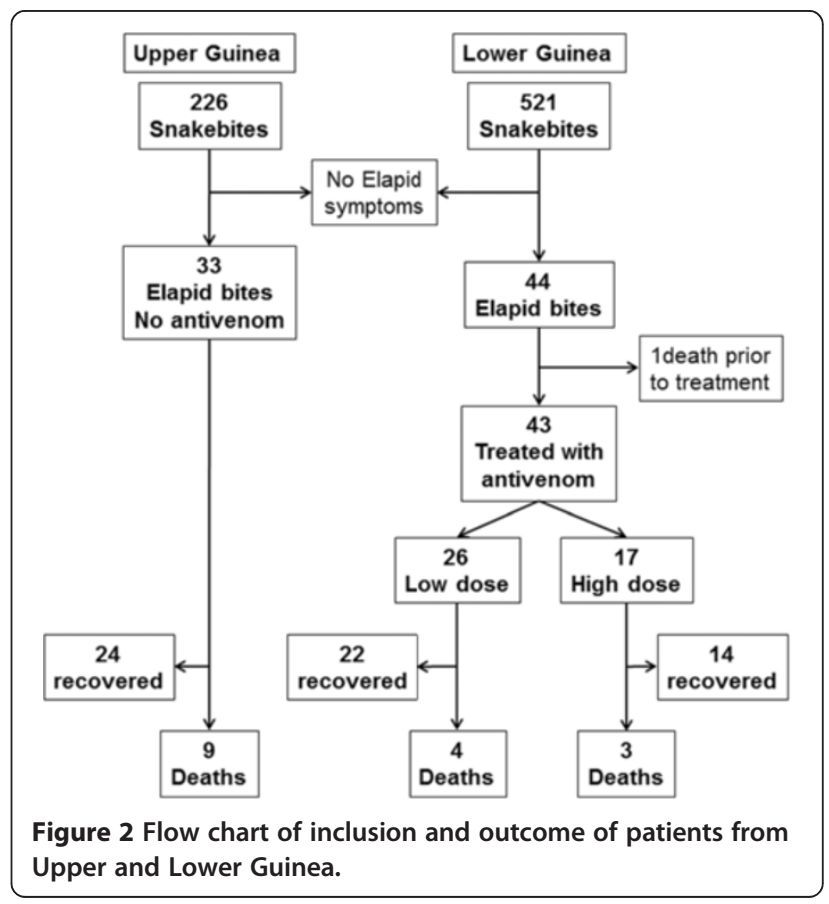


Table 2 Symptoms and time to death in patients of group 1

\begin{tabular}{|c|c|c|c|c|c|c|}
\hline $\mathbf{N}$ & Time of the bite & Sex and age & Treatment & Symptoms at presentation & Time of the death & $\begin{array}{l}\text { Time between } \\
\text { bite and death }\end{array}$ \\
\hline 1 & 8:10 a.m. & $M-15$ & Traditional & Hypersalivation; blurred vision & 10:45 a.m. & $2: 35$ \\
\hline 2 & 9:00 p.m. & $M-43$ & Symptomatic & Breathlessness & 4:00 a.m. & 7:00 \\
\hline 3 & 3:20 p.m. & $F-56$ & Traditional and symptomatic & Weakness; sweat & 11:10 p.m. & $7: 50$ \\
\hline 4 & 11:00 a.m. & $M-23$ & Symptomatic & Ptosis & 7:00 p.m. & $8: 00$ \\
\hline 5 & 0:50 p.m. & $M-17$ & Traditional & Blurred vision & 2:15 p.m. & $1: 25$ \\
\hline 6 & 4:20 p.m. & $F-32$ & Traditional and symptomatic & Consciousness disorders & 1:00 p.m. & $20: 40$ \\
\hline 7 & 8:00 p.m. & $F-8$ & Symptomatic & Blurred vision and consciousness disorders & 12:30 a.m. & $16: 30$ \\
\hline 8 & 5:00 p.m. & $F-36$ & Traditional & Hypersalivation, consciousness disorders & 4:10 a.m. & $11: 10$ \\
\hline 9 & 2:30 p.m. & $M-51$ & Traditional and symptomatic & Local bleeding; breathlessness & Day 2: 6:00 p.m. & $27: 30$ \\
\hline
\end{tabular}

Table 3 Symptoms and time to death in patients of group 2 (low dose of antivenom)

\begin{tabular}{|c|c|c|c|c|c|c|}
\hline Patient & $\begin{array}{l}\text { Time between bite } \\
\text { and presentation }\end{array}$ & $\begin{array}{c}\text { Clinical score } \\
\text { on arrival }\end{array}$ & Snake species & $\begin{array}{c}\text { Vials of } \\
\text { antivenom }\end{array}$ & Associated symptoms & Outcome \\
\hline 8 & 3 & 4 & D. viridis & 2 & & Recovery $\mathrm{H}_{6}$ \\
\hline 16 & 21 & 5 & D. viridis & 4 & & Recovery $\mathrm{H}_{6}$ \\
\hline 17 & 11 & 3 & & 1 & & Recovery $\mathrm{H}_{6}$ \\
\hline 19 & 18 & 6 & D. polylepis & 4 & Edema & Death $\mathrm{H}_{7}$ \\
\hline 20 & 48 & 2 & & 1 & & Recovery $\mathrm{H}_{3}$ \\
\hline 26 & 5 & 5 & D. viridis & 4 & & Recovery $\mathrm{H}_{6}$ \\
\hline 27 & 6 & 6 & & 4 & Local bleeding & Recovery $\mathrm{H}_{6}$ \\
\hline 29 & 2 & 6 & & 2 & Local bleeding & Death $\mathrm{H}_{1}$ \\
\hline 33 & 47 & 2 & & 1 & & Recovery $\mathrm{H}_{3}$ \\
\hline 37 & 2 & 1 & & 2 & & Recovery $\mathrm{H}_{3}$ \\
\hline 38 & 13 & 3 & & 1 & Edema & Recovery $\mathrm{H}_{3}$ \\
\hline 53 & 15 & 1 & & 1 & Local bleeding and edema & Recovery $\mathrm{H}_{3}$ \\
\hline 59 & 4 & 4 & & 2 & Bleeding & Recovery $\mathrm{H}_{3}$ \\
\hline 71 & 10 & 4 & & 4 & Edema & Recovery $\mathrm{H}_{6}$ \\
\hline 77 & 20 & 3 & D. viridis & 2 & Edema & Recovery $\mathrm{H}_{3}$ \\
\hline 87 & 7 & 5 & D. viridis & 6 & & Recovery $\mathrm{H}_{48}$ \\
\hline 88 & 4 & 5 & & 4 & & Recovery $\mathrm{H}_{24}$ \\
\hline 119 & 3 & 5 & D. viridis & 2 & & Recovery $\mathrm{H}_{24}$ \\
\hline 123 & 3 & 4 & & 1 & & Recovery $\mathrm{H}_{6}$ \\
\hline 124 & 10 & 5 & & 2 & & Recovery $\mathrm{H}_{24}$ \\
\hline 130 & 3 & 1 & & 2 & Local bleeding & Recovery $\mathrm{H}_{6}$ \\
\hline 134 & 14 & 3 & Naja sp. & 4 & Edema & Death $\mathrm{H}_{4}$ \\
\hline 138 & 4 & 2 & & 3 & & Recovery $\mathrm{H}_{6}$ \\
\hline 141 & 2 & 2 & D. polylepis & 6 & & Death $\mathrm{H}_{7}$ \\
\hline 148 & 6 & 4 & Naja sp. & 2 & Edema & Recovery $\mathrm{H}_{12}$ \\
\hline 149 & 1 & 2 & N. melanoleuca & 1 & Local bleeding & Recovery $\mathrm{H}_{6}$ \\
\hline
\end{tabular}

$\mathrm{H}$ : hour after initial antivenom dose. 
Table 4 Symptoms and time to death in patients of group 3 (high dose of antivenom); one death (\#11) was not recorded because the patient died before treatment, less than three hours after the bite

\begin{tabular}{|c|c|c|c|c|c|c|}
\hline Patient & $\begin{array}{l}\text { Time between bite } \\
\text { and presentation }\end{array}$ & $\begin{array}{l}\text { Clinical score } \\
\text { on arrival }\end{array}$ & Snake species & $\begin{array}{c}\text { Vials of } \\
\text { antivenom }\end{array}$ & $\begin{array}{l}\text { Associated } \\
\text { symptoms }\end{array}$ & Evolution \\
\hline 1 & 2 & 2 & & 4 & & Death $\mathrm{H}_{2}$ \\
\hline 2 & 7 & 4 & D. viridis & 4 & Edema & Recovery $\mathrm{H}_{31}$ \\
\hline 3 & 7 & 4 & Naja sp. & 4 & Edema & Recovery $\mathrm{H}_{79}$ \\
\hline 4 & 2 & 1 & & 4 & & Recovery $\mathrm{H}_{50}$ \\
\hline 5 & 3 & 2 & Naja sp. & 4 & & Recovery $\mathrm{H}_{51}$ \\
\hline 6 & 3 & 5 & D. polylepis & 4 & Local bleeding & Death $\mathrm{H}_{1}$ \\
\hline 7 & 1 & 1 & N. nigricollis & 4 & Edema & Recovery $\mathrm{H}_{49}$ \\
\hline 8 & 2 & 4 & & 4 & Local bleeding & Death $\mathrm{H}_{2}$ \\
\hline 9 & 4 & 1 & & 4 & Local bleeding & Recovery $\mathrm{H}_{28}$ \\
\hline 10 & 1 & 2 & & 4 & & Recovery $\mathrm{H}_{49}$ \\
\hline 12 & 4 & 4 & Naja sp. & 4 & Edema & Recovery $\mathrm{H}_{52}$ \\
\hline 13 & 4 & 1 & & 4 & & Recovery $\mathrm{H}_{28}$ \\
\hline 14 & 5 & 6 & & 4 & Edema & Recovery $\mathrm{H}_{29}$ \\
\hline 15 & 6 & 4 & D. viridis & 4 & & Recovery $\mathrm{H}_{30}$ \\
\hline 16 & 5 & 3 & & 4 & & Recovery $\mathrm{H}_{53}$ \\
\hline 17 & 10 & 6 & & 6 & & Recovery $\mathrm{H}_{34}$ \\
\hline 18 & 18 & 2 & & 4 & & Recovery $\mathrm{H}_{66}$ \\
\hline
\end{tabular}

H: hour after initial antivenom dose.

of envenomation were evaluated by means of scores (Table 1) [10].

Antivipmyn ${ }^{\circledR}$ Africa, manufactured by Bioclon Institute (Mexico), is composed of highly purified lyophilized F $\left(\mathrm{ab}^{\prime}\right)_{2}$ immunoglobulin fragments [11]. It is produced by immunization of horses with the venoms of Bitis gabonica, B. arietans, Echis ocellatus, E. leucogaster, E. pyramidum, Naje haje, N. melanoleuca, N. nigricollis, N. pallida, Dendroaspis viridis and D. polylepis. Preclinical testing indicated a specific neutralizing potency of more than $250 \mathrm{LD}_{50}$ per vial against all relevant species [11]. Administration of the antivenom was always by direct intravenous push as detailed elsewhere and modified as indicated in the Results section [9].

Statistical analysis used Wilcoxon rank sum test for time to presentation, score and time to death, and Student's $t$ test for treatment doses, with $\mathrm{p}=0.05$.

\section{Results and discussion}

In the region of Upper Guinea, we analyzed 226 records of patients bitten between 2005 and 2006. At the Pasteur Institute of Guinea, in Lower Guinea, 521 patients were treated from 2009 to 2011.

Table 5 Comparison of score and time to death in the $\mathbf{3}$ groups

\begin{tabular}{|c|c|c|c|}
\hline & $\begin{array}{l}\text { Group } 1 \\
\text { (no antivenom) }\end{array}$ & $\begin{array}{l}\text { Group } 2 \\
\text { (low dose) }\end{array}$ & $\begin{array}{l}\text { Group } 3 \\
\text { (high dose) }\end{array}$ \\
\hline Number of cases & 33 & 26 & 17 \\
\hline Score at presentation & Cured patients $=?$ & Cured patients $=4[2-5]$ & Cured patients $=2.5[1.3-4]$ \\
\hline Median [Q:0.25-0.75] & Fatalities $=5[3-6]^{*}$ & Fatalities $=4.5[2.8-6]$ & Fatalities = 4 [3-4.5] \\
\hline Mean of antivenom \pm SD $[95 \% \mathrm{Cl}]$ & 0 & $26.2 \pm 5.9 \mathrm{~mL}$ & $41.2 \pm 2.3 \mathrm{~mL}$ \\
\hline Number of fatalities & $9(27.3 \%)$ & $4(15.4 \%)$ & $3(17.6 \%)$ \\
\hline Time to presentation & - & Cured patients $=5$ [3.3-9.3] & Cured patients $=3$ [3.3-10] \\
\hline Median [Q: 0.25-0.75] & & Fatalities = 2.5 [2-6.8] & Fatalities = 2 [2-8] \\
\hline Time to death & $8[7-13.5]$ & $5.5[3.3-7]$ & $4[4-4]$ \\
\hline Median [Q:0.25-0.75] & & & \\
\hline
\end{tabular}

*Score established retrospectively from recorded clinical symptoms. 
The data collected as well as the outcomes are summarized in Figure 2 and Tables 2, 3, 4, 5. There were no significant differences either in the neurological scores on arrival or in the delay of treatment between the three groups. Administration of antivenom, independently of dose, did not significantly reduce CFR between the untreated group from Upper Guinea and either group treated in Lower Guinea.

Data collection varied among the three groups due to the conditions of the surveys and the treatment protocols. The study in Upper Guinea was retrospective, a fact that restricted the available information. In the two groups from Lower Guinea, the treatment protocol changed due to the apparently low efficacy of the Antivipmyn ${ }^{\circledR}$ Africa antivenom, as well as the modalities of patient surveillance and the recovery criteria, which introduced some intergroup heterogeneity. Some comparisons could not be made among all groups, such as the delay in receiving a consultation (this variable was not available for the untreated group) or the time between bite and recovery in surviving patients (since none of the groups followed the same recovery criteria). In addition, Elapid species differ slightly in these two aspects (Table 6). In the end, the only parameters usable for comparison were the score on arrival, the dose of antivenom, case fatality rate and the time elapsed between bite and death (Table 6). As a consequence, comparability between groups, as well as patient series described in the literature, is limited. It appears, however, that treatment failures are common even when employing high doses of antivenom associated with intensive symptomatic treatment (mechanical ventilation, prostigmine etc.).

Our analysis of the records from the two health centers allowed us to identify 77 patients who, on arrival, presented neurological troubles strongly suggestive of envenomation by Elapidae. In some cases species could be identified either by examination of the specimen or by a description. Furthermore, the observed symptoms

Table 6 Elapid species and distribution in Upper and Lower Guinea

\begin{tabular}{|c|c|c|c|}
\hline Species & $\begin{array}{l}\text { Upper } \\
\text { Guinea }\end{array}$ & $\begin{array}{l}\text { Lower } \\
\text { Guinea }\end{array}$ & Symptoms \\
\hline Naja nigricollis & Common & Common & $\begin{array}{l}\text { Local necrosis, } \\
\text { neurotoxic signs }\end{array}$ \\
\hline Naja katiensis & Common & Absent & $\begin{array}{l}\text { Neurotoxic signs, } \\
\text { local necrosis }\end{array}$ \\
\hline Naja melanoleuca & Common & Common & Neurotoxic signs \\
\hline Dendroaspis viridis & Present & Common & $\begin{array}{l}\text { Neurotoxic signs, } \\
\text { muscarinic syndrome }\end{array}$ \\
\hline Dendroaspis polylepis & Present & Present & $\begin{array}{l}\text { Neurotoxic signs, } \\
\text { muscarinic syndrome }\end{array}$ \\
\hline Pseudohaje nigra & Absent & Rare & $\begin{array}{l}\text { No envenomation } \\
\text { recorded }\end{array}$ \\
\hline
\end{tabular}

permitted, with a little experience, educated guesses of the species or at least genera responsible for the envenomation (Table 6). Some species of Naja are responsible for an isolated neurological syndrome (syndrome cobraïque) (Figure 3), or associated with local necrosis in the case of envenomations by Naja nigricollis and N. katiensis (both spitting cobras). Dendroaspis (in Guinea, D. viridis and $D$. polylepis) envenomation is also associated with the syndrome, a muscarinic symptomatology manifested by abundant sweat, sialorrhea, vomit, diarrhea and mydriasis [12] (Figure 4). We do not have information on envenomations by Pseudohaje nigra.

A delay until consultation, which is detailed only for patients in groups 2 and 3, appears to be a decisive factor insofar as it delays treatment, which is more effective the earlier it is administered [13-15]. The lack of significance between the groups could result from the small number of patients. Paradoxically, the delay in consultation is longer (although not significantly) in patients who recovered in comparison to those who died (Table 5). However, some severely envenomed patient could have died before reaching the health center. But there is no evidence to support this hypothesis. In addition, the time between bite and fatality in group 3 is remarkably shorter and significantly different from that of the other two groups. The duration of hospitalization is also much shorter, which suggests either that envenomations were more severe (even if scores on arrival were similar) or that shorter delays were declared.

The efficacy of Antivipmyn ${ }^{\circledR}$ Africa in these cases is therefore directly questioned. There is no reason to doubt its experimental neutralization capacity, but these results do not seem to be transposed to the clinical situation [11]. Dosage does not seem to be the issue, as the same results are apparent at lower and higher doses. In our study, doubling the initial dose did not lead to a difference in the maximal dose administered

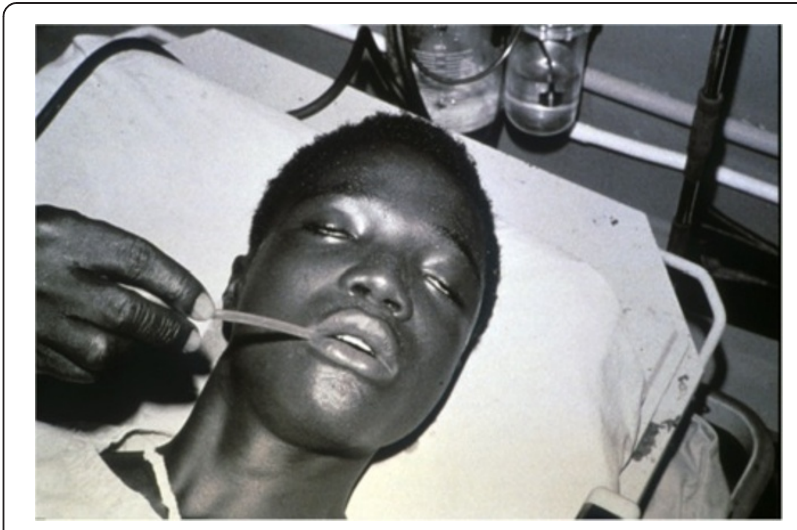

Figure 3 Neurotoxic syndrome due to Naja melanoleuca bite (note pathognomonic ptosis) Photo by E. Stahel. 


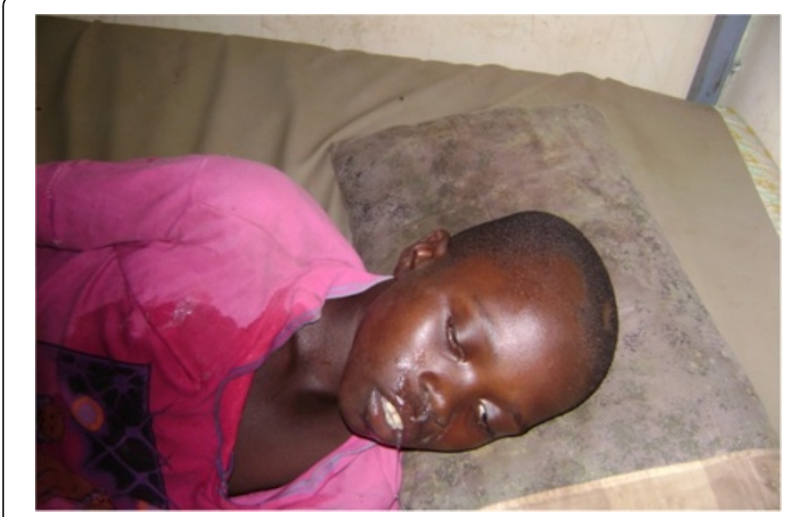

Figure 4 Associated neurotoxic and muscarinic syndromes due to Dendroaspis sp bite (note hypersalivation and profuse sweating) Photo by C. Baldé.

to the patients $(60 \mathrm{~mL})$, a fact that suggests that the criteria for re-administration of antivenom were not apparent during the monitoring of the patients. But despite demonstrable neutralization in the animal model, it is possible that the venom of a particular species (of a total of four possible ones in Lower Guinea) is poorly neutralized by the antivenom in humans; given the small sample of patients and the lack of unambiguous snake identification in most of them, this could skew the overall results and mask some measure of overall efficacy. It is also possible that the therapeutic window is simply very narrow for some or all venoms.

More generally in Elapid envenomations, such low apparent clinical efficacy has also been observed by numerous authors who have obtained similar results, even at much higher doses (Table 7). Furthermore, in all other studies, antivenom use was associated with mechanical ventilation on demand, as well as other symptomatic treatments such as cholinesterase inhibitors. These were not available for patients in the present study. Although the species, and therefore the toxicity and mode of action of their venoms, are different, and the antivenoms - whose neutralizing capacities are also variable - are not the same, it is important to note that the treatment of Elapidae envenomations is less effective than treatment of those inflicted by Viperidae. In fact, the doses reported by numerous authors (surpassing occasionally even a hundred vials, a tendency which confirms a low level of efficacy) seem unreasonable, with regard to both the quantity of heterologous protein administered and the cost of treatment, already prohibitive for extremely poor patients even at much lower doses.

In hemorrhagic envenomations in the West African savanna, a rapid arrest of hemorrhage and coagulopathy was apparent after antivenom administration, requiring no additional care to remove most patients from immediate
Table 7 Antivenom doses and mortality observed in the literature

\begin{tabular}{|c|c|c|c|c|c|}
\hline Countries & $\begin{array}{l}\text { Patients } \\
\text { (n) }\end{array}$ & $\begin{array}{l}\text { Mean doses } \\
\text { (mL [range]) }\end{array}$ & $\begin{array}{l}\text { \# deaths } \\
\text { (CFR) }\end{array}$ & $\begin{array}{l}\text { Supportive } \\
\text { measures* }\end{array}$ & Reference \\
\hline Guinea & 26 & $\begin{array}{c}25 \mathrm{ml} \\
{[10-60]}\end{array}$ & $4(15 \%)$ & No & $\begin{array}{l}\text { Group } 2 \\
\text { this study }\end{array}$ \\
\hline Guinea & 17 & $\begin{array}{c}40 \mathrm{~mL} \\
{[40-60]}\end{array}$ & $3(18 \%)$ & No & $\begin{array}{l}\text { Group } 3 \\
\text { this study }\end{array}$ \\
\hline India & 28 & $150 \mathrm{~mL}$ & 0 & VS & [16] \\
\hline India & 27 & $\begin{array}{c}600 \mathrm{~mL} \\
{[300-1.600]}\end{array}$ & $3(11 \%)$ & VS & [16] \\
\hline Sri Lanka & 87 & $\begin{array}{l}>100 \mathrm{~mL} \\
{[100-200]}\end{array}$ & $5(6 \%)$ & VS & [17] \\
\hline Sri Lanka & 25 & $\begin{array}{c}100 \mathrm{~mL} \\
{[80-200]}\end{array}$ & $2(8 \%)^{\S}$ & VS & [18] \\
\hline India & 37 & $150 \mathrm{~mL}$ & $11(22 \%)^{*}$ & VS; AC & [19] \\
\hline Taiwan & 22 & $\begin{array}{c}30 \mathrm{~mL} \\
{[10-100]}\end{array}$ & 0 & VS & [20] \\
\hline $\begin{array}{l}\text { Papua New } \\
\text { Guinea }\end{array}$ & 139 & $50 \mathrm{~mL}$ & $6(4.3 \%)$ & VS & [13] \\
\hline $\begin{array}{l}\text { Papua New } \\
\text { Guinea }\end{array}$ & 31 & $25 \mathrm{~mL}$ & 0 & VS; AC & [13] \\
\hline India & 14 & $60 \mathrm{~mL}$ & $1(7 \%)$ & VS & [21] \\
\hline India & 12 & $120 \mathrm{~mL}$ & 0 & VS & [21] \\
\hline Thailand & 68 & $100 \mathrm{~mL}$ & 0 & VS & [22] \\
\hline India & 86 & $\begin{array}{c}510 \mathrm{~mL} \\
{[50-1900]}\end{array}$ & $3(3.5 \%)$ & VS & [23] \\
\hline $\begin{array}{l}\text { Papua New } \\
\text { Guinea }\end{array}$ & 156 & $50 \mathrm{~mL}$ & $3(1.9 \%)$ & VS & [14] \\
\hline Vietnam & 42 & $\begin{array}{c}50 \mathrm{~mL} \\
{[50-100]}\end{array}$ & 0 & VS & [24] \\
\hline Thailand & 85 & $\begin{array}{c}40 \mathrm{~mL} \\
\text { [10-200] }\end{array}$ & $1(1 \%)$ & VS & [25] \\
\hline
\end{tabular}

VS: ventilatory support; $A C$ : anticholinesterase; ${ }^{\S}$ the patients died from extensive necrosis; ${ }^{*}$ three patients died before treatment.

danger of life-threatening hemorrhage [7-9]. The lack of therapeutic response in neurotoxic envenomations, however, suggests that antivenom alone may not suffice to ensure a sufficiently rapid recovery to prevent respiratory failure and death. Under the extremely precarious conditions of this study, potential benefits of antivenom administration, such as a speedier recovery from respiratory paralysis, would be masked by the unavailability of assisted ventilation.

One possibility is that the antivenom has a low efficacy after neurotoxins are fixed on the neuromuscular receptors, which usually happens in the first few hours after the bite [26]. In this view, the problem is immunochemical: those epitopes recognized by the antibodies would be masked on receptor-bound toxins and this would in turn 
prevent toxin-antibody complex formation, neutralization and elimination.

A second hypothesis that merits attention is pharmacokinetic: the toxin-antibody encounter does not occur because the antigen and the antibody are not found in the same biological compartment. The antivenom is largely present in the vascular compartment [27]. It is in this compartment that antigen-antibody complex formation occurs, provided that the relevant venom components are there as well. It has been clearly shown that Viperidae venoms are found in the blood, where they are bound by antivenom [28]. To the best of our knowledge, it has never been shown that neurotoxins from Elapidae venoms were present in high proportion in the vascular compartment, nor that neurotoxins are bound by $\mathrm{F}\left(\mathrm{ab}^{\prime}\right)_{2}$ after intravenous administration.

\section{Conclusion}

During a clinical study in Guinea under true field conditions, the administration of purified immunoglobulin fragments to treat neurotoxic enevenomation due to Elapidae has proven a disappointment, in agreement with the results of numerous other clinical studies.

The hypothesis of insufficient venom neutralization is difficult to maintain because, on one hand, the experimental neutralization of venoms is generally acceptable and, on the other hand, this divergence has been noted for many elapid venoms and antivenoms throughout the world. Alternatively, a hypothesis of an absence of toxin-antibody complex formation merits consideration; it could come about by epitope masking on receptor-bound toxins and/or by a failure of the antibodies to encounter the relevant toxins due to pharmacokinetic constraints. In the first case, the only recourse would be very early administration of antivenom or the development of neutralizing antibodies against epitopes not masked on receptor-bound toxins. In the second case, another route of antivenom administration should be considered.

In the meantime, it is advisable to administer antivenom as early as possible after the bite to attempt to eliminate available venom antigens and to secure assisted ventilation in case the patient presents the onset of respiratory distress.

\section{Consent}

Written informed consent was obtained from the patients for publication of this study and any accompanying images.

\section{Competing interests}

The authors declare that there are no conflicts of interest.

\section{Authors' contributions}

JPC, RPS and AM designed the study. MCB, JPC and AM wrote the protocol. $M C B$ and MYB performed the field study. MCB, JPC analysed the results. JPC wrote the draft. All authors corrected and validated the paper. MCB and JPC are garantors of the paper.

\section{Author details}

${ }^{1}$ Institut Pasteur de Guinée, Kindia, Guinée. ${ }^{2}$ Institut de Recherche pour le Développement, Cotonou, Bénin. ${ }^{3}$ Centre d'Etude et de Recherche sur le Paludisme Associé à la Grossesse et à l'Enfance, Cotonou, Bénin. ${ }^{4}$ Instituto de Biotecnología, Universidad Nacional Autónoma de México, Cuernavaca, México.

Received: 1 October 2012 Accepted: 30 November 2012

Published: 28 March 2013

\section{References}

1. Chippaux JP: The development and use of immunotherapy in Africa. Toxicon 1998, 36(1):1503-1506.

2. Chippaux JP: Snakebite in Africa: current situation and urgent needs. In Reptile venoms and toxins. Edited by Mackessy SP. Boca Raton: Taylor, Francis/CRC Press; 2009:445-465.

3. Chippaux JP: The treatment of snake bites: analysis of requirements and assessment of therapeutic efficacy in tropical Africa. In Perspectives in molecular toxinology. Edited by Ménez A. Chichester: John Wiley \& Sons, Ltd; 2002:457-472.

4. Chippaux JP: Estimate of the burden of snakebites in sub-Saharan Africa: a meta-analytic approach. Toxicon 2011, 57(4):586-599.

5. Stock RP, Massougbodji A, Alagón A, Chippaux JP: Bringing antivenom to Sub-Saharan Africa. Nat Biotechnol 2007, 25(2):173-177.

6. Theakston RD, Warrell DA, Griffiths E: Report of a WHO workshop on the standardization and control of antivenoms. Toxicon 2003, 41(5):541-557.

7. Chippaux JP, Lang J, Eddine SA, Fagot P, Rage V, Peyrieux JC, et al: Clinical safety of a polyvalent $F\left(a b^{\prime}\right) 2$ equine antivenom in 223 African snake envenomations: a field trial in Cameroon. Trans R Soc Trop Med Hyg 1998, 92(6):657-662.

8. Chippaux JP, Lang J, Amadi-Eddine S, Fagot P, Le Mener V: Treatment of snake envenomations by a new polyvalent antivenom composed of highly purified $\mathrm{F}\left(\mathrm{ab} \mathrm{b}^{\prime}\right) 2$ : results of a clinical trial in northern Cameroon Am J Trop Med Hyg 1999, 61(6):1017-1018.

9. Chippaux JP, Massougbodji A, Stock RP, Alagón A: Clinical trial of an F(ab') 2 polyvalent equine antivenom for African snakebites in Benin. Am J Trop Med Hyg 2007, 77(3):538-546.

10. Baldé MC, Chippaux JP, Boiro MY, Stock R, Massougbodji A: Étude clinique de la tolérance et de l'efficacité d'un sérum anti-ophidien polyvalent $F\left(a b^{\prime}\right) 2$ pour l'Afrique à Kindia, Guinée. Bull Soc Pathol Exot 2012, 105(3):157-161.

11. Ramos-Cerrillo B, de Roodt AR, Chippaux JP, Olguín L, Casasola A, Guzmán G, et al: Characterization of a new polyvalent antivenom (Antivipmyn Africa ${ }^{\circledR}$ ) against African vipers and elapids. Toxicon 2008, 52(8):881-888.

12. Chippaux JP, Courtois B, Roumet D, Éyébiyi R: Envenimation par morsure de Mamba (Dendroaspis viridis): à propos d'une observation à évolution favorable. Med Trop 1977, 37(5):545-549.

13. Lalloo DG, Trevett AJ, Korinhona A, Nwokolo N, Laurenson IF, Paul M, et al: Snake bites by the Papuan taipan (Oxyuranus scutellatus canni): paralysis, hemostatic and electrocardiographic abnormalities, and effects of antivenom. Am J Trop Med Hyg 1995, 52(6):525-531.

14. Trevett AJ, Lalloo DG, Nwokolo NC, Naraqi S, Kevau $\|_{\text {, }}$ Theakston RD, et al: The efficacy of antivenom in the treatment of bites by the Papuan taipan (Oxyuranus scutellatus canni). Trans R Soc Trop Med Hyg 1995, 89(3):322-325.

15. Trevett AJ, Lalloo DG, Nwokolo NC, Naraqi S, Kevau IH, Theakston RD, et al: Failure of 3,4-diaminopyridine and edrophonium to produce significant clinical benefit in neurotoxicity following the bite of Papuan taipan (Oxyuranus scutellatus canni). Trans R Soc Trop Med Hyg 1995, 89(4):444-446.

16. Agarwal R, Aggarwal AN, Gupta D, Behera D, Jindal SK: Low dose of snake antivenom is as effective as high dose in patients with severe neurotoxic snake envenoming. Emerg Med J 2005, 22(6):397-399.

17. Ariaratnam CA, Sheriff MH, Theakston RD, Warrell DA: Distinctive epidemiologic and clinical features of common krait (Bungarus caeruleus) bites in Sri Lanka. Am J Trop Med Hyg 2008, 79(3):458-462.

18. Kularatne SA, Budagoda BD, Gawarammana IB, Kularatne WK: Epidemiology, clinical profile and management issues of cobra (Naja naja) bites in Sri Lanka: first authenticated case series. Trans $R$ Soc Trop Med Hyg 2009, 103(9):924-930.

19. Bawaskar HS, Bawaskar PH: Envenoming by the common krait (Bungarus caeruleus) and Asian cobra (Naja naja): clinical manifestations and their management in a rural setting. Wilderness Environ Med 2004, 15(4):257-266. 
20. Chieh-Fan C, Tzeng-Jih L, Wen-Chi H, Hua-Wei Y: Appropriate antivenom doses for six types of envenomations caused by snakes in Taiwan. J Venom Anim Toxins ind Trop Dis 2009, 15(3):479-490.

21. Paul V, Pratibha S, Prahlad KA, Earali J, Francis S, Lewis F: High-dose anti-snake venom versus low-dose anti-snake venom in the treatment of poisonous snake bites - a critical study. J Assoc Physicians India 2004, 52:14-17.

22. Pochanugool C, Limthongkul S, Wilde H: Management of thai cobra bites with a single bolus of antivenin. Wilderness Environ Med 1997, 8(1):20-23.

23. Sharma N, Chauhan S, Faruqi S, Bhat $P$, Varma S: Snake envenomation in a north Indian hospital. Emerg Med J 2005, 22(2):118-120.

24. Trinh KX, Khac QL, Trinh LX, Warrell DA: Hyponatraemia, rhabdomyolysis, alterations in blood pressure and persistent mydriasis in patients envenomed by Malayan kraits (Bungarus candidus) in southern Viet Nam. Toxicon 2010, 56(6):1070-1075.

25. Wongtongkam N, Wilde H, Sitthi-Amorn C, Ratanabanangkoon K: A study of Thai cobra (Naja kaouthia) bites in Thailand. Mil Med 2005, 170(4):336-341.

26. Boulain JC, Ménez A: Neurotoxin-specific immunoglobulins accelerate dissociation of the neurotoxine-acetylcholine receptor complex. Science 1982, 217(4561):732-733

27. Sevcik C, Salazar V, Díaz P, D'Suze G: Initial volume of a drug before it reaches the volume of distribution: pharmacokinetics of $F\left(a b^{\prime}\right) 2$ antivenoms and other drugs. Toxicon 2007, 50(5):653-665.

28. Rivière G, Choumet V, Saliou B, Debray M, Bon C: Absorption and elimination of viper venom after antivenom administration. J Pharmacol Exp Ther 1998, 285(2):490-495.

doi:10.1186/1678-9199-19-6

Cite this article as: Baldé et al:: Use of antivenoms for the treatment of envenomation by Elapidae snakes in Guinea, Sub-Saharan Africa. Journal of Venomous Animals and Toxins including Tropical Diseases 2013 19:6.

\section{Submit your next manuscript to BioMed Central and take full advantage of:}

- Convenient online submission

- Thorough peer review

- No space constraints or color figure charges

- Immediate publication on acceptance

- Inclusion in PubMed, CAS, Scopus and Google Scholar

- Research which is freely available for redistribution 